\title{
Comment les Bozo sont sortis de leur trou. Habitat et mode de vie dans le delta intérieur du Niger
}

\section{Claude Meillassoux}

\section{(2) OpenEdition \\ 12 Journals}

Édition électronique

URL : https://journals.openedition.org/tc/931

DOI : $10.4000 /$ tc. 931

ISSN : 1952-420X

Éditeur

Éditions de l'EHESS

\section{Édition imprimée}

Date de publication : 1 février 1986

ISSN : 0248-6016

\section{Référence électronique}

Claude Meillassoux, " Comment les Bozo sont sortis de leur trou. Habitat et mode de vie dans le delta intérieur du Niger », Techniques \& Culture [En ligne], 6 | 1986, mis en ligne le 24 janvier 2006, consulté le 29 septembre 2022. URL : http://journals.openedition.org/tc/931 ; DOI : https://doi.org/10.4000/tc 931

Ce document a été généré automatiquement le 29 septembre 2022.

Tous droits réservés 
Comment les Bozo sont sortis de leur trou. Habitat et mode de vie dans le delta intérieur du Niger

Claude Meillassoux 